\title{
Anti-Poliovirus Antibody
}

National Cancer Institute

\section{Source}

National Cancer Institute. Anti-Poliovirus Antibody. NCI Thesaurus. Code C123800.

An antibody produced in response to exposure to poliovirus. 